\title{
Metastatic Merkel cell carcinoma (MCC) of pancreas and breast: a unique case
}

\author{
Spiridon Vernadakis ${ }^{1 *}$, Demetrios Moris ${ }^{1,3+}$, Agnes Bankfalvi $^{2}$, Nikolaos Makris ${ }^{1}$ and Georgios C Sotiropoulos ${ }^{1}$
}

\begin{abstract}
Merkel cell carcinoma (MCC) is a rare potentially fatal skin tumor affecting older and immunosuppressed individuals. It is highly malignant with high rates of metastasis and poor survival.

We present a case of a 67-year-old woman with a palpable mass in the upper abdomen. An abdominal CT revealed a mass in the tail of the pancreas. Two weeks before, lumpectomy of a $3.5 \mathrm{~cm}$ tumor of the left breast had been performed. Histology showed a primary neuroendocrine carcinoma of the mammary gland. The patient's medical history was significant for a $0.7 \times 0.9 \mathrm{~cm}$ MCC removed from her left forearm 2.5 years ago. There was no evidence of vascular involvement or peritoneal disease and by all criteria was resectable. A somatostatin receptor scintigraphy showed an enhanced uptake in the pancreatic tail region. The tumor was immunohistochemically strong staining for synaptophysin and CD56. The diagnosis of a metastatic-MCC in the tail of the pancreas was made. Further histological investigation of the prior removed neuroendocrine breast tumor and the MCC of the left forearm confirmed neuroendocrine origin and identical histology to the previously resected MCC of the left forearm. In this article, we aim to highlight that MCC has the potential to spread even in unusual organs, such as pancreas or breast, and therefore a diligent follow-up should be applied in patients with MCC.
\end{abstract}

Keywords: Merkel cell carcinoma, Merkel cell polyomavirus, Metastasis, Pancreatic tumors

\section{Background}

Merkel cell carcinoma (MCC) is a rare, potentially fatal skin tumor affecting older, mainly white people and younger immunosuppressed individuals [1]. It is a highly malignant tumor of the skin with high rates of metastasis and poor survival. Its incidence rate is rising and is currently approximately $0.6 / 100,000$ cases per year $[1,2]$. We present a unique case of concomitant metastatic MCC to pancreatic tail and breast.

\section{Case presentation}

A 67-year-old woman was referred to Department of General, Visceral and Transplantation Surgery of University Hospital Essen with a palpable mass in the upper abdomen. An abdominal CT revealed a large mass in the tail of the pancreas $(10 \times 14 \mathrm{~cm})$ (Figure 1) without evidence of other peritoneal disease during staging investigation for a suspected carcinoma of the left breast. Two weeks

\footnotetext{
* Correspondence: svernadakis@yahoo.com

${ }^{\dagger}$ Equal contributors

'Department of General, Visceral and Transplantation Surgery, University

Hospital Essen, Hufelandstr. 55, Essen 45122, Germany

Full list of author information is available at the end of the article
}

previously, lumpectomy of a $3.5 \mathrm{~cm}$ tumor of the left breast had been performed by gynecologists. Sentinel lymph node examination was negative. Histology showed a primary poorly differentiated neuroendocrine carcinoma of the mammary gland. The patient's medical history was significant for mediastinal sarcoidosis and a $0.7 \times 0.9 \mathrm{~cm} \mathrm{MCC}$ removed from her left forearm 2.5 years previous, which was Merkel cell polyomavirus (MCV) DNA positive after quantitative PCR. No viral DNA was found in peripheral blood. Postoperative adjuvant external beam radiation therapy of 52 Gy was given on the left forearm. Clinically, the patient reported abdominal discomfort and weight loss of $8 \mathrm{~kg}$ over the previous 4 months. Although the pancreatic mass was large, there was no evidence of vascular involvement or peritoneal disease and by all criteria was resectable. A somatostatin receptor scintigraphy showed enhanced uptake in the pancreatic tail region and excluded other involved areas. An extended distal pancreatectomy and splenectomy along with resection of the splenic flexure of the colon were performed and the tumor was removed intact. Pathological examination revealed a $14 \times 10 \times 8 \mathrm{~cm}$ solid mass of small cells in the pancreatic

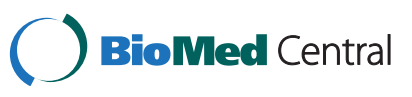




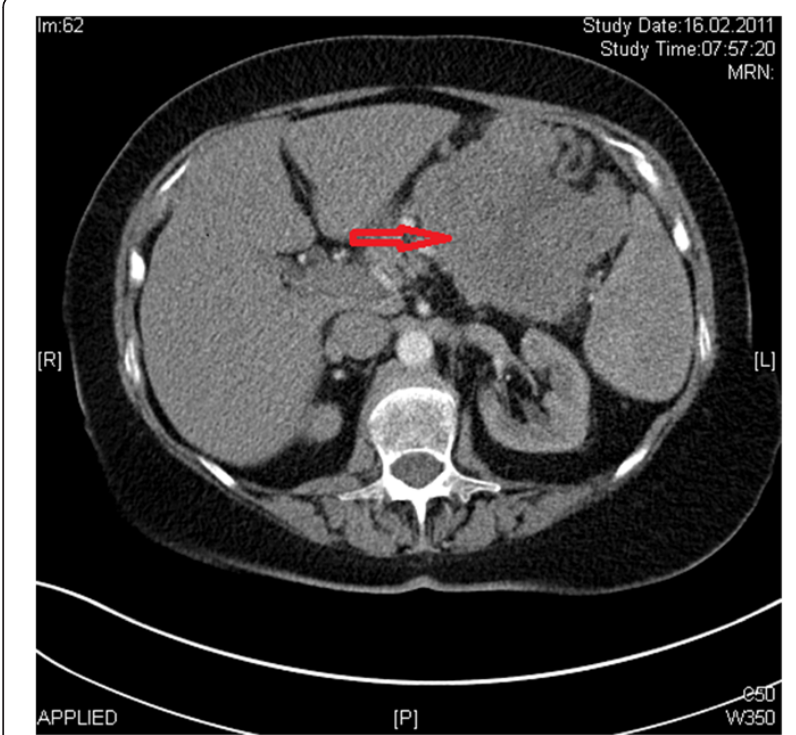

Figure $1 \mathrm{CT}$ scan of the abdomen demonstrating a large mass in relation to the pancreatic tail.

tail. Grossly, the mass displayed a glassy cut surface, containing areas of necrosis and hemorrhage. The spleen and four identified lymph nodes were negative for tumor as well as negative for the presence of MCV. Histological evaluation revealed a mitotic, highly active tumor (mitotic count 35 per high power field) with endocrine architecture of solid formations (regular, round nuclei with little cytoplasm). The tumor had immunohistochemically strong staining for synaptophysin, CD56, and in some areas, chromogranin. The tumor cells were strongly positive for cytokeratin 18 with a typically perinuclear granular (dot-like) reaction and also for cytokeratin 20 and the PAN-cytokeratin-specific antibody CK-MNF-116 with a paranuclear "dot-like" pattern (Figure 2A). There was no expression of gastrin, glucagon, insulin, serotonin, somatostatin, TTF-1, or CD117. The proliferative activity (Ki-67) reached approximately $80 \%$ (Figure $2 \mathrm{~B}$ ). Evaluating the presence of MCV due to the positivity of the primary tumor, the metastatic tumor was also MCV positive. Based on the clinical, histological, and viral status of the tumor, the diagnosis of a metastatic-MCC in the tail of the pancreas was made. Further histological investigation of the prior removed neuroendocrine breast tumor and the MCC of the left forearm confirmed neuroendocrine origin and identical histology to the previously resected MCC of the left forearm (similar viral profile as well). The patient was referred to oncologists for further evaluation and therapeutic treatment. At 2-year follow-up, the patient was still disease-free, without any complications related to disease progression or recurrence.

\section{Discussion}

MCC is a rare neuroendocrine skin carcinoma with aggressive biological behavior. MCC appears in approximately $50 \%$ of cases on the head and neck [1,2]. The second most common sites are the extremities (40\%) followed by trunk and genitals (less than 10\%) [1,2]. MCC is a carcinoma of the elderly, with a mean age at the time of initial diagnosis of 70 years. It occurs more frequently in immunosuppressed individuals. Many patients who are diagnosed with MCC have a history of other cancers suggesting that MCC may also share etiologic factors with other malignancies [1-3]. Patient symptoms are usually local or secondary to tumor growth or lymph node involvement. Most patients have localized disease at initial presentation (70-80\%) [2,4]; the majority develop metastatic disease, either synchronously or metachronously with a frequency varying from 20-75\% [4]. It has a penchant for local recurrence and distant metastasis to various sites, including regional lymph nodes, distant skin, lung, liver, testis, and other rare organs such as the pancreas [1-3,5]. Patients with lymph node metastases

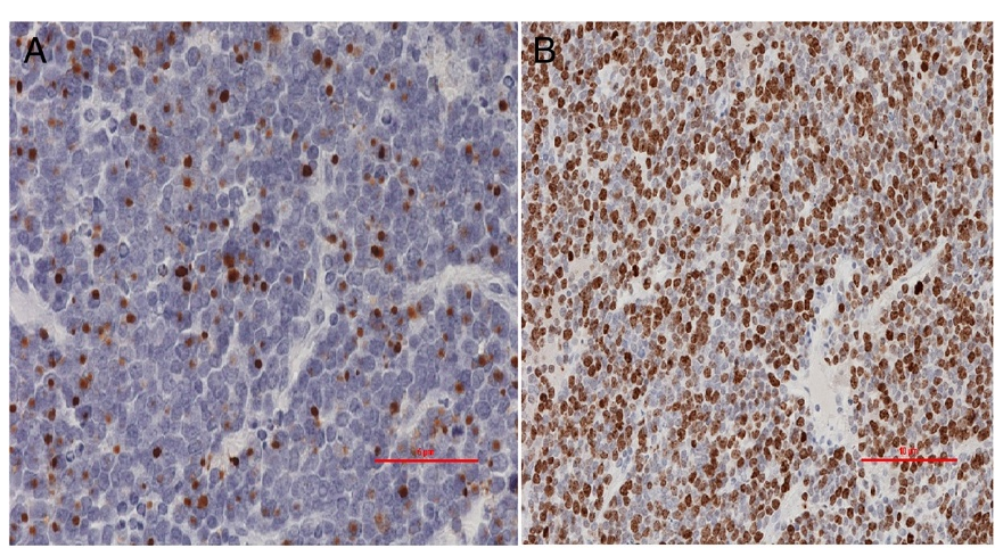

Figure 2 Histology of the pancreatic tumor - MCC metastasis. (A) Strong immunohistochemical staining against CK20 (original magnification $\times 400$ ). (B) Strong proliferative activity Ki-67 of $80 \%$ (original magnification $\times 200$ ). 
demonstrate a two- to three-fold higher mortality rate when compared with those without nodal involvement [1].

To our knowledge, there have been only nine previously described cases of MCC affecting the pancreas [2-10]. So far, this is the first case of concomitant pancreatic and breast metastatic MCC disease [2,5] that also evaluates the viral profile of primary and metastatic tumors. There is no information available about the exact incidence of pancreatic metastases of MCC. Secondary neoplasms of the pancreas have been reported to comprise 2$3.9 \%$ of pancreatic tumors. In an analysis published by Adsey et al. [6], one case of MCC metastatic to the pancreas was found from a pool of 38 cases of metastatic pancreatic disease. Optimal treatment is based on experience gained from the study of retrospective cases and, especially in the setting of local-regional failure, it remains a major challenge for oncologists. The best current treatment of localized disease appears to be surgery, followed by adjuvant therapy and perhaps systemic chemotherapy [4]. In some cases, definitive radiation therapy could be considered and justified if surgical resection is not possible [4]. The staging of MCC includes a whole-body CT scan because of the frequent high-proliferation index and poor differentiation of the tumor, with the aim of identifying metastatic involvement of soft tissues, sometimes associated with lytic bone lesions [7].

Finally, the recently evaluated role of $\mathrm{MCV}$ in the pathogenesis and clinical behavior of MCC should be highlighted. MCV is detected in low levels in normal skin (normal flora), in inflammatory and neoplastic cutaneous diseases, and in non-lesional skin from patients with MCC [11]. MCV is detected in as many as $80-90 \%$ of MCCs studied [11] presenting with higher viral load of MCV DNA in MCC compared with benign and other malignant human tissue samples [12]. Its contribution to tumorigenesis is based on the integration of virus before clonal expansion of tumor, the presence of signature viral mutations in tumors, and the expression of viral oncoproteins such as large and small $\mathrm{T}$ antigen [11-15]. MCV appears to be associated with certain morphologies of MCC. MCCs with unusual differentiation containing neuroendocrine and non-neuroendocrine elements (complex MCC) or combined MCC with squamous cell carcinoma contained no MCV [13].

MCV-positive and -negative MCCs have differing pathologies. Histologically, MCV-positive MCC tumors have more-regular, rounder nuclei with a smaller cytoplasm than MCV-negative MCC tumors, which have irregular nuclei and a larger cytoplasm [13-15]. The method of choice in identifying MCV is PCR due to its potential to further increase sensitivity for detecting tissue disease by identifying submicroscopic tumor deposits [13].

Table 1 summarizes the previously described cases of MCC metastatic to the pancreas.

\section{Conclusions}

MCC is a rare potentially fatal skin tumor with high rates of metastasis and poor survival. We presented a unique case of concomitant MCC in breast and pancreas originating from left forearm. We aim to highlight that MCC has the potential to spread even in unusual organs, such as pancreas or breast, so a diligent follow-up should be applied in patients with MCC.

Table 1 Summary of the described cases of MCC metastatic to the pancreas

\begin{tabular}{|c|c|c|}
\hline Author & Year & Presentation \\
\hline Safadi R et al. [8] & 1996 & $\begin{array}{l}\text { A 69-year-old woman with chronic lymphocytic leukemia who developed MCC and obstructive jaundice due to } \\
\text { pancreatic metastases of the MCC. }\end{array}$ \\
\hline Bachmeyer C et al. [7] & 2002 & $\begin{array}{l}\text { A 57-year-old man with MCC on the left lower eyelid. The patient died of generalized carcinomatosis after metastatic } \\
\text { MCC invading the stomach and pancreas. }\end{array}$ \\
\hline Ouellette JR et al. [2] & 2004 & $\begin{array}{l}\text { A 64-year-old man with obstructive jaundice approximately two years after having a MCC resected from his finger. He } \\
\text { underwent a successful pancreaticoduodenectomy with pathology confirming metastatic MCC. }\end{array}$ \\
\hline Adsey et al. [6] & 2004 & $\begin{array}{l}\text { One case from a pool of } 38 \text { metastatic tumors of the pancreas. No data about the age and the clinical presentation } \\
\text { available. }\end{array}$ \\
\hline Bachmann J et al. [5] & 2005 & $\begin{array}{l}\text { An 82-year-old woman presented with an abdominal mass, } 2 \text { years prior she had an excision done on her eyebrow } \\
\text { that was reported as MCC. Final histopathology of the mass was an endocrine carcinoma in the pancreatic tail } \\
\text { consistent with metastatic MCC. }\end{array}$ \\
\hline Hizawa K et al. [9] & 2007 & $\begin{array}{l}\text { An 85-year-old woman with MCC on the right eyelid. The patient died of an intra-abdominal metastatic MCC that } \\
\text { directly invaded the stomach, pancreas and distal duodenum. }\end{array}$ \\
\hline Dim DC et al. [3] & 2009 & A 79-year-old woman with a large pancreatic tail mass and a history of MCC of the upper extremity. \\
\hline Krejčí K et al. [10] & 2010 & $\begin{array}{l}\text { A 62-year-old man who developed a MCC in the right gluteal region } 8 \text { years after combined kidney-pancreas } \\
\text { transplantation. The tumor was generalized and metastasized into the pancreatic graft. The patient died } 9 \text { months } \\
\text { after diagnosis. }\end{array}$ \\
\hline Bernstein J et al. [4] & 2012 & $\begin{array}{l}\text { A 56-year-old male presented with a palpable femoral lymph node of a left posterior thigh nodule. Histopathological } \\
\text { examination revealed a MCC. A heterogeneous lesion in the pancreatic tail was identified by endoscopic ultrasound. }\end{array}$ \\
\hline
\end{tabular}




\section{Consent}

Written informed consent was obtained from the patient for publication of this Case report and any accompanying images. A copy of the written consent is available for review by the Editor-in-Chief of this journal.

\section{Abbreviations}

MCC: Merkel cell carcinoma; MCV: Merkel cell polyomavirus.

\section{Competing interests}

The authors who have taken part in this study declare that they do not have anything to disclose regarding funding or conflict of interest with respect to this manuscript.

\section{Authors' contributions}

SV analyzed and interpreted the patient's data regarding the disease and the operation. DM was a major contributor in writing and revising the manuscript. $A B$ performed the histological examination of the tissues. NM wrote the first draft of the manuscript. GS supervised the manuscript. All authors read and approved the final manuscript. SV and DM contributed equally.

\section{Author details}

'Department of General, Visceral and Transplantation Surgery, University Hospital Essen, Hufelandstr. 55, Essen 45122, Germany. ${ }^{2}$ Institute of Pathology and Neuropathology, University Hospital Essen, Hufelandstr. 55, Essen 45122, Germany. ${ }^{3} 1$ st Department of Surgery, Laikon General Hospital, National and Kapodistrian University of Athens, Athens 11527, Greece.

Received: 16 February 2013 Accepted: 22 September 2013 Published: 7 October 2013

\section{References}

1. Becker JC: Merkel cell carcinoma. Ann Oncol 2010, 21(Supp.7):81-85.

2. Ouellette JR, Woodyard L, Toth L, Termuhlen PM: Merkel cell carcinoma metastatic to the head of the pancreas. JOP 2004, 5:92-96.

3. Dim DC, Nugent SL, Darwin P, Peng HQ: Metastatic Merkel cell carcinoma of the pancreas mimicking primary pancreatic endocrine tumor diagnosed by endoscopic ultrasound-guided fine needle aspiration cytology. Acta Cytol 2009, 53(2):223-228.

4. Bernstein J, Adeniran AJ, Cai G, Theoharis CG, Ustun B, Beckman D, Aslanian HR, Harigopal M: Endoscopic ultrasound-guided fine-needle aspiration diagnosis of merkel cell carcinoma metastatic to the pancreas. Diagn Cytopathol 2012. Epub ahead of print.

5. Bachmann J, Kleeff J, Bergmann F, Shrikhande SV, Hartschuh W, Büchler MW, Friess $\mathrm{H}$ : Pancreatic metastasis of Merkel cell carcinoma and concomitant insulinoma: Case report and literature review. World J Surg Oncol 2005, 3:58.

6. Adsay NV, Andea A, Basturk O, Kilinc N, Nassar H, Cheng JD: Secondary tumors of the pancreas: an analysis of a surgical and autopsy database and review of the literature. Virchows Arch 2004, 444(6):527-535.

7. Bachmeyer C, Alovor G, Chatelain D, Khuoy L, Turc Y, Danon O, Laurette F, Cazier A, N'Guyen V: Cystic metastasis of the pancreas indicating relapse of Merkel cell carcinoma. Pancreas 2002, 24:103-105.

8. Safadi R, Pappo O, Okon E, Sviri S, Eldor A: Merkel cell tumor in a woman with chronic lymphocytic leukemia. Leuk Lymphoma 1996, 20(5-6):509-511.

9. Hizawa K, Kurihara S, Nakamori M, Nakahara T, Matsumoto T, lida M: An autopsy case of Merkel cell carcinoma presenting aggressive intraabdominal metastasis and duodenal obstruction. Nihon Shokakibyo Gakkai Zasshi 2007, 104(9):1383-1386.

10. Krejčí K, Tichý T, Horák P, Ciferská H, Hajdúch M, Srovnal J, Trojanec R, Zezulová M, Zlevorová M, Kalinová L, Zadražil J: Merkel cell carcinoma of the gluteal region with ipsilateral metastasis into the pancreatic graft of a patient after combined kidney-pancreas transplantation. Onkologie 2010, 33(10):520-524.

11. Feng $H$, Shuda $M$, Chang $Y$, Moore PS: Clonal integration of a polyomavirus in human Merkel cell carcinoma. Science 2008, 319:1096-1100.

12. Loyo M, Guerrero-Preston R, Brait M, Hoque MO, Chuang A, Kim MS, Sharma R, Liegeois NJ, Koch WM, Califano JA, Westra WH, Sidransky D: Quantitative detection of Merkel cell virus in human tissues and possible mode of transmission. Int J Cancer 2010, 126:2991-2996.

13. Schrama D, Peitsch WK, Zapatka M, Kneitz H, Houben R, Eib S, Haferkamp S, Moore PS, Shuda M, Thompson JF, Trefzer U, Pföhler C, Scolyer RA, Becker $J C$ : Merkel cell polyomavirus status is not associated with clinical course of Merkel cell carcinoma. J Invest Dermatol 2011, 131:1631-1638.

14. Higaki-Mori H, Kuwamoto S, Iwasaki T, Kato M, Murakami I, Nagata K, Sano H, Horie Y, Yoshida Y, Yamamoto O, Adachi K, Nanba E, Hayashi K: Association of Merkel cell polyomavirus infection with clinicopathological differences in Merkel cell carcinoma. Hum Pathol 2012, 43(12):2282-2291.

15. Jaeger T, Ring J, Andres C: Histological, immunohistological, and clinical features of merkel cell carcinoma in correlation to Merkel cell polyomavirus status. J Skin Cancer 2012, 2012:983421.

\section{doi:10.1186/1477-7819-11-261}

Cite this article as: Vernadakis et al:: Metastatic Merkel cell carcinoma (MCC) of pancreas and breast: a unique case. World Journal of Surgical Oncology 2013 11:261.

\section{Submit your next manuscript to BioMed Central and take full advantage of:}

- Convenient online submission

- Thorough peer review

- No space constraints or color figure charges

- Immediate publication on acceptance

- Inclusion in PubMed, CAS, Scopus and Google Scholar

- Research which is freely available for redistribution 